\title{
Acute Release of Thyrotropin in the Newborn
}

\author{
D. A. Fisher and W. D. Odell \\ From the Departments of Pediatrics and Medicine, Harbor General Hospital, \\ Torrance, California 90509, and the University of California School of Medicine, \\ Los Angeles, California 90024
}

A B S T RAC T Measurements of serum thyrotropin (TSH) concentrations were conducted in maternal and fetal blood during labor and delivery and the early postnatal and neonatal periods. Mean TSH concentration was significantly higher in cord blood $(9.5 \mu \mathrm{U} / \mathrm{ml})$ than maternal blood $(3.9 \mu \mathrm{U} / \mathrm{ml})$, a finding suggesting a fetalmaternal TSH gradient at term. Serum TSH concentration in the newborn increased rapidly to mean levels of $60 \mu \mathrm{U} / \mathrm{ml}$ at $10 \mathrm{~min}$ and $86 \mu \mathrm{U} / \mathrm{ml}$ at $30 \mathrm{~min}$ of age. Between $30 \mathrm{~min}$ and 3-4 hr serum levels decreased rapidly, then fell more gradually to a mean concentration of $13 \mu \mathrm{U} / \mathrm{ml}$ at $48 \mathrm{hr}$. The half-time of the decrease in serum TSH concentration between 30 and $90 \mathrm{~min}$ was $77 \mathrm{~min}$, a value slightly greater than the half-time of disappearance of radioiodinated TSH measured in adults. This indicates that the early high rate of TSH secretion in the newborn ceases by $30 \mathrm{~min}$, and that the rapid rise and fall in serum TSH concentrations may represent release of stored pituitary TSH. A more chronic TSH hypersecretion persisted throughout the first $24-48 \mathrm{hr}$ of extrauterine life. Measurements of serum PBI concentrations were conducted in a separate group of maternal and cord blood samples and in the newborn infants during the first $48 \mathrm{hr}$ of extrauterine life to relate the TSH and serum hormonal iodine concentration changes. Serum protein-bound iodine (PBI) concentrations were similar in maternal and cord blood, increased significantly by $4 \mathrm{hr}$ of age in the newborn, and peaked at about $24 \mathrm{hr}$, presumably in response to the TSH hypersecretion. The pattern of TSH hypersecretion was similar in infants delivered vaginally and by caesarean section. Maternal serum TSH concentrations were stable throughout the perinatal period. Warming the infants at $99-103^{\circ} \mathrm{F}$ during the first $3 \mathrm{hr}$ of life did not prevent the early, acute release of thyrotropin. Cooling of warm infants at room temperature $\left(72-78^{\circ} \mathrm{F}\right)$ between 3 and $4 \mathrm{hr}$ resulted in a decrease in mean rectal temperature of $3.3^{\circ} \mathrm{F}$ and produced a significant increment in serum TSH concentration. These data suggest

Received for publication 14 March 1969 and in revised form 29 April 1969. that the mechanism of the early, acute release of thyrotropin in the newborn may involve a potent stimulus other than cooling. However, the increase in serum TSH stimulated by delayed (3-4 hr) cooling indicates that neonatal hyperthyroxinemia is, at least, augmented by extrauterine cooling. Thus, cold exposure is capable of increasing TSH secretion in humans.

\section{INTRODUCTION}

Danowski and colleagues (1) in 1951 first reported that the serum protein-bound iodine (PBI) concentration of the newborn infant increases to hyperthyroid levels during the first hours and days of extrauterine life. This observation has been amply confirmed (2-6), and increases in triiodothyronine- ${ }^{181} \mathrm{I}$ erythrocyte or resin uptake $(4,7-9)$ and in free thyroxine (6) have also been demonstrated. These data indicate and quantitative measurements have confirmed (5) that alterations in maximal binding capacity of thyroxine-binding serum proteins are not responsible for the neonatal hyperthyroxemia. An associated high rate of thyroidal radioiodine clearance in the newborn led Fisher, Oddie, and Burroughs $(4,10)$ to suggest that the hyperthyroxinemia was the result of a high rate of thyrotropin (TSH) release. In agreement with this hypothesis, we (11) and Utiger, Wilber, Cornblath, Harm, and Mack (12) have previously reported that TSH concentrations are elevated in the sera of newborn infants during the early hours of extrauterine life. Fisher, Oddie, and Makoski $(4,13)$ also reported that the degree of hyperthyroxinemia can be significantly reduced by warming the infant during the first $48 \mathrm{hr}$ of life and suggested that neonatal hyperthyroxinemia may be, at least in part, a response to extrauterine cooling.

The present report results from our continuing studies of this interesting phenomenon and defines the details of the postnatal hyperthyrotropinemia in the newborn and its temporal relationship to the hyperthyroxinemia. We also report, for the first time in man, an influence of body cooling on serum TSH concentrations. 


\section{METHODS}

Serum TSH concentrations were measured by use of the double-antibody radioimmunoassay technique of Odell and coworkers $(14,15)$. Extensive correlative studies have shown that this radioimmunoassay (described in reference 15) gives similar potency estimates to those obtained by specific bioassay over a wide range of TSH potencies. PBI concentrations were measured by a modification of the alkaline ashing technique described by Foss, Hankes, and Van Slyke (16).

Measurements of serum TSH concentrations were first conducted on maternal and cord blood samples from a series of seven healthy mothers and their newborn term infants kept at ambient nursery temperature $\left(72-78^{\circ} \mathrm{F}\right)$. A polyethylene catheter was inserted under sterile conditions into the umbilical vein of the infant within a few minutes of birth to facilitate atraumatic blood sampling, and 1-2 ml blood samples was obtained at 10,30,60,90, and $120 \mathrm{~min}$. The umbilical catheter was then removed. In selected instances blood samples also were obtained by venipuncture at 24 and (or) $48 \mathrm{hr}$. Infant deep rectal temperature was monitored at birth, at 10,30,60, and $90 \mathrm{~min}$ and at 2, 3, and $4 \mathrm{hr}$.

TSH was measured in a second group of 15 infants during warming or during warming with subsequent cooling over the first $4 \mathrm{hr}$ of extrauterine life. These infants were transferred immediately after birth to an incubator and maintained at an environmental temperature of $99-103^{\circ} \mathrm{F}$. Five infants were warmed for $4 \mathrm{hr}$. An additional 10 infants were warmed for $3 \mathrm{hr}$. after which time they were removed from the incubators and maintained at ambient nursery temperature $\left(72-78^{\circ} \mathrm{F}\right)$. Rectal temperature was monitored as described above. Maternal and cord blood samples were obtained, and umbilical vein catheters were inserted to facilitate blood sampling; samples were obtained at $10,30,60$, and $90 \mathrm{~min}$ and at $3,3 \frac{1}{2}$, and $4 \mathrm{hr}$. No more than six 1-2 $\mathrm{ml}$ samples were obtained from each infant during the postpartum neonatal period. The umbilical catheters were removed at $4 \mathrm{hr}$. Selected $24-$ or $48-\mathrm{hr}$ specimens also were obtained by venipuncture.

Finally, in order to monitor the increment in serum hormonal iodine during the first 2 days, blood samples for measurement of PBI were obtained by venipuncture from a separate group of 12 infants maintained at ambient nursery temperature $\left(72-78^{\circ} \mathrm{F}\right)$. Maternal and cord blood specimens were obtained, and blood was drawn from the infants at 4,24 , and $48 \mathrm{hr}$.

All infants were products of full term, uncomplicated pregnancies of multiparous mothers and weighed from 2450 to $4680 \mathrm{~g}$ (average $3295 \mathrm{~g}$ ). The neonatal course was uneventful with a single exception. Analgesia during labor was minimal; local anesthesia or regional (pudendal) block and occasional nitrous oxide-oxygen inhalent anesthesia were employed during delivery. Written, informed consent was obtained from every mother before delivery and before any analgesia.

\section{RESULTS}

Results of the serum TSH concentrations are collated in Table I. Cord blood TSH values exceeded maternal values in all except one instance. The difference between mean cord blood and mean maternal TSH concentrations was highly significant $(P<0.001)$. In all of the seven infants maintained at ambient room temperature a profound postnatal increase in serum TSH occurred. Maximal values were observed at $30 \mathrm{~min}$ in all except two infants. (Sny peaked at $10 \mathrm{~min}$; Wal peaked at 60 min.) Mean values for the group were 65 and $94 \mu \mathrm{U} / \mathrm{ml}$ at 10 and $30 \mathrm{~min}$ respectively. The mean value decreased rapidly during the next $90 \mathrm{~min}$, and by $2 \mathrm{hr}$ was $48 \mu \mathrm{U} /$ $\mathrm{ml}$. By 24 and $48^{\circ} \mathrm{hr}$ TSH concentrations were only slightly higher than cord blood values. Rectal temperatures in these seven infants averaged $97.5^{\circ} \mathrm{F} 3 \mathrm{hr}$ after birth. A rapid and profound cooling in the extrauterine environment is indicated; the nadir in rectal temperature was usually observed about $30 \mathrm{~min}$ after birth.

The PBI data are collated in Table II. Maternal and cord blood PBI concentrations were similar $(P=0.3)$. PBI concentrations in the infants increased rapidly in response to the TSH hypersecretion; the mean concentration by $4 \mathrm{hr}$ was $9.4 \mu \mathrm{g} / 100 \mathrm{ml}$. A peak value of $10.9 \mu \mathrm{g} / 100 \mathrm{ml}$ was observed at $24 \mathrm{hr}$.

TSH data from infants warmed in incubators during the early hours of life are shown in Table I. In these infants, too, a rapid and profound increment in serum TSH concentration was observed. The mean $30 \mathrm{~min}$ TSH concentration measured in the incubated infants $(82 \mu \mathrm{U} / \mathrm{ml})$ was not different from that in the nonincubated infants. Rectal temperatures in the 15 incubated infants averaged $98.3^{\circ} \mathrm{F}$ (range $97-100^{\circ} \mathrm{F}$ ) at $10 \mathrm{~min}$, $99.0^{\circ} \mathrm{F}$ (range $98-100.3^{\circ} \mathrm{F}$ ) at $30 \mathrm{~min}$, and $99.9^{\circ} \mathrm{F}$ (range $99-101.2^{\circ} \mathrm{F}$ ) $3 \mathrm{hr}$ after delivery. As indicated by the slight decrement in mean $10 \mathrm{~min}$ temperature, some cooling occurred in 10 of the 15 infants. The serum TSH values in five infants whose rectal temperatures were consistently $99^{\circ} \mathrm{F}$ or higher during incubation are shown in Fig. 1, for comparison with values in the seven infants maintained at ambient nursery temperatures. The one infant in whom no early acute TSH release was noted ( $\mathrm{McC}$, Table I) was the only infant whose APGAR $^{1}$ score was below 8 at 1 and 5 min. Two other infants (not included in the present study) with low APGAR scores (1-4 at 1 and $5 \mathrm{~min}$ ) have been studied. In these infants, too, the early acute hyperthyrotropinemia was not observed. Since the serum TSH concentrations in incubated and nonincubated infants were similar, TSH values from the two groups of infants (Table II) were pooled and are shown with the PBI data (from the separate group of 12 infants) in Fig. 2.

The fall in TSH concentrations after the $30 \mathrm{~min}$ peak was rapid. Fig. 3 shows a semilogarithmic plot of the pooled mean serum TSH concentration data between 30 and $90 \mathrm{~min}$. The decrease appears linear with a half-time of $77 \mathrm{~min}$.

\footnotetext{
${ }^{1}$ APGAR, the arbitrary score proposed by Dr. Virginia Apgar for the semiquantitative assessment of infant oxygenation and cardiovascular status during the immediate neonatal period (17). Scores range from 0 to 1 in infants with severe hypoxia to 10 in normal infants.
} 
Fig. 4 is a plot of serum TSH concentrations $30-140$ min before delivery, at delivery, and 30-40 min postpartum in five mothers. Maternal TSH levels were stable throughout labor and during the early postnatal period.

Fig. 5 shows the postnatal serum TSH concentration patterns in four caesarean section infants plotted against the background of the seven "control" infants kept at ambient nursery temperature. The early acute release of thyrotropin also was observed in these infants.

The high concentration of serum TSH observed as early as 10 min after birth in both incubated and nonincubated infants indicated that the TSH secretion stimulus occurred at or very early after delivery. Since it was very difficult to completely eliminate skin cooling during the first 1-2 min after birth, the possibility existed that a cold stimulus occurred which was not prevented by incubation, even in the five infants whose rectal temperature did not fall. Therefore a second study was designed: 10 infants were incubated (warmed) for $3 \mathrm{hr}$ and then cooled (removed from incubator) for 1 $\mathrm{hr}$. Mean rectal temperature of these 10 infants at $3 \mathrm{hr}$ was $100^{\circ} \mathrm{F}$ (range $99.5-101.5^{\circ} \mathrm{F}$ ) and at $4 \mathrm{hr}$ was $96.7^{\circ} \mathrm{F}$ (range $95.5-97.5^{\circ} \mathrm{F}$ ) indicating a marked cooling during this $1 \mathrm{hr}$ period.

The serum TSH concentration data in these infants are summarized in Table $I$ and shown graphically in Fig. 6. Increases in serum TSH occurred in all except one infant. In some, the peak TSH concentration was observed at $3 \frac{1}{2} \mathrm{hr}$, in others at $4 \mathrm{hr}$. The mean per cent increments in serum TSH concentration at $3 \frac{1}{2}$ and $4 \mathrm{hr}$ in these 10 infants are plotted in Fig. 7 for comparison with the per cent change in serum TSH in the five control infants incubated for the entire $4 \mathrm{hr}$ period (see Table I). The increase in serum TSH in response to

TABLE"I

Newborn Serum TSH Concentrations

\begin{tabular}{|c|c|c|c|c|c|c|c|c|c|c|c|c|}
\hline \multirow[b]{2}{*}{ Infant } & \multicolumn{2}{|c|}{ At birth } & \multicolumn{5}{|c|}{ Age in minutes } & \multicolumn{5}{|c|}{ Age in hours } \\
\hline & Mat.* & Cord & 10 & 30 & 60 & 90 & 120 & 3 & $3 \frac{3}{2}$ & 4 & 24 & 48 \\
\hline \multicolumn{13}{|c|}{ Infants kept at ambient room temperature $\left(72-78^{\circ} \mathrm{F}\right)$} \\
\hline Ann & 6.7 & 9.2 & 83 & 116 & 92 & 66 & 80 & & & & 8.6 & 5.6 \\
\hline Sny & 4.3 & 7.6 & 99 & 53 & 50 & 46 & 36 & & & & 17.4 & 14.0 \\
\hline Gor & 2.6 & 12.2 & 36 & 100 & 83 & 73 & 66 & & & & 18.0 & 16.0 \\
\hline Con & 3.0 & 9.6 & 40 & 149 & 92 & 19 & 14 & & & & - & 2.5 \\
\hline Che & 4.0 & 8.9 & 73 & 83 & 55 & 25 & 21 & & & & - & - \\
\hline Wal & 8.7 & 16.0 & 50 & 83 & 97 & 80 & 67 & & & & $18 . \dot{0}$ & 12.0 \\
\hline Mon & 2.5 & 14.3 & 73 & 74 & 63 & 43 & 50 & & & & 15.0 & 5.0 \\
\hline \multicolumn{13}{|c|}{ Infants warmed $\left(99-103^{\circ} \mathrm{F}\right)$ during first $4 \mathrm{hr}$} \\
\hline Cha & 3.3 & 3.7 & - & 78 & 52 & 41 & & 72 & 53 & 57 & - & 14.0 \\
\hline Kud $\ddagger$ & 4.0 & 6.6 & - & 80 & - & 42 & & 24 & 24 & 18 & - & - \\
\hline Vas $\ddagger$ & 2.3 & 3.0 & - & 90 & 66 & 60 & & 54 & 54 & 48 & 33.0 & 20.0 \\
\hline Mik & 2.5 & 12.0 & 一 & 90 & 75 & 55 & & 36 & 32 & 31 & 10.0 & - \\
\hline Don & 4.3 & 11.9 & - & - & 43 & 45 & & 37 & 33 & 31 & - & 5.6 \\
\hline \multicolumn{13}{|c|}{ Infants warmed $(3 \mathrm{hr})$ and cooled $(1 \mathrm{hr})$} \\
\hline $\mathrm{McK}$ & 4.0 & 2.5 & 73 & 133 & - & 70 & & 47 & - & 60 & - & 18.0 \\
\hline Bes & 3.0 & 13.0 & 45 & 58 & - & 27 & & 16 & 20 & 24 & - & - \\
\hline Sel & 5.0 & 12.0 & 83 & 112 & - & 60 & & 53 & 120 & 95 & - & 23.0 \\
\hline Asc & 3.3 & 8.3 & - & 66 & 57 & 47 & & 31 & 37 & 27 & - & - \\
\hline Mon & - & - & - & - & 47 & 32 & & 23 & 29 & 32 & - & 18.0 \\
\hline Whi & - & 3.8 & - & 65 & 44 & 44 & & 39 & 45 & 32 & - & - \\
\hline Bon $\ddagger$ & 3.5 & 16.0 & - & 70 & 94 & 56 & & 26 & 20 & 17 & - & - \\
\hline Pol & 2.7 & 18.0 & - & 110 & - & 68 & & 30 & 65 & 60 & - & - \\
\hline $\mathrm{McC}$ & 5.0 & 7.0 & 11 & 13 & - & 12 & & 13 & - & 31 & - & - \\
\hline Vilf & 2.3 & 4.3 & - & 100 & 76 & 69 & & 50 & 55 & 53 & - & - \\
\hline Mean & 3.9 & 9.5 & 61 & 86 & 68 & 49 & 48 & 37 & & & 17.1 & 12.8 \\
\hline SEM§ & 0.36 & 1.00 & 7.9 & 6.8 & 4.8 & 3.9 & 9.4 & 4.2 & & & 3.0 & 1.9 \\
\hline
\end{tabular}

All values are expressed in terms of microunits per milliliter.

* Maternal serum.

$\ddagger$ Caesarean section infants.

$\S$ Standard error. 
cooling was statistically significant. The mean per cent change in 10 cooled infants between 3 and $4 \mathrm{hr}$ was $+38 \pm 17.7 \%$; that in five warmed infants was -17 $\pm 2.0 \%,(P=0.01$, values recorded as mean $\pm \mathrm{SEM})$.

\section{DISCUSSION}

Serum immunoassayable TSH concentrations were significantly higher in cord blood then in maternal blood at the time of delivery. This observation is in agreement with that of Utiger and colleagues (12). It is not in agreement, however, with observations of maternal-cord blood TSH concentrations reported earlier by investigators using the TSH bioassay techniques. Costa and coworkers (18), using the in vitro tissue culture bioassay of Bottari, reported that maternal serum TSH concentrations exceeded newborn values about sixfold. Yamazaki, Noguchi, and Slingerland (19) using the McKenzie bioassay observed that the difference between the levels of TSH in maternal and cord blood was not significant.

Cross-reaction between human chorionic gonadotropin (HCG) and the TSH antiserum in the radioimmunoassay for TSH cannot explain the maternal cord blood TSH concentration differences; excess HCG (30 IU) was added to each tube in the radioimmunoassay. The dose-response curve for HCG was relatively flat (20); a doubling of HCG concentration $(30-60 \mathrm{IU} / \mathrm{ml})$ produced only a $2 \%$ decrease in per cent counts bound (precipitated). Maternal HCG concentrations averaged $31 \mathrm{IU} / \mathrm{ml}$ and cord blood values $0.5 \mathrm{IU} / \mathrm{ml}$ (21). Thus HCG concentrations are 60 times higher in maternal

TABLE II

PBI Measurements on Newborn Serum

\begin{tabular}{lcccrr}
\hline & \multicolumn{5}{c}{ PBI concentration } \\
\cline { 2 - 6 } Infant & Mat.* & Cord & $4 \mathrm{hr}$ & $24 \mathrm{hr}$ & $\mathbf{4 8} \mathrm{hr}$ \\
\hline & & \multicolumn{5}{c}{$\mu \mathrm{g} / 100 \mathrm{ml}$} \\
Wh & 6.2 & 5.2 & 9.4 & 9.7 & 7.6 \\
Joi & 7.0 & 7.2 & 9.4 & 11.7 & 10.3 \\
Tho & 9.5 & 9.1 & 9.4 & 12.4 & 11.4 \\
Blu & 6.2 & 7.2 & 7.3 & 8.2 & 7.8 \\
Joh & 10.0 & 6.7 & 9.5 & 10.1 & 9.0 \\
Fla & 7.9 & 9.4 & 12.5 & 14.5 & 12.2 \\
Smi & 8.6 & 8.0 & 11.7 & 13.3 & 13.0 \\
Wil & 7.4 & 4.5 & 6.9 & 9.3 & 7.8 \\
Nei & 5.9 & 5.9 & 8.8 & 11.7 & 10.2 \\
Jac & 5.9 & 6.4 & 6.6 & 9.3 & 8.6 \\
McN & 6.7 & 5.4 & 9.3 & 9.9 & 6.1 \\
Hay & 7.1 & 7.1 & 11.6 & 10.8 & 9.7 \\
Mean & 7.4 & 6.8 & 9.4 & 10.9 & 9.5 \\
SEM & 0.40 & 0.43 & 0.54 & 0.54 & 0.59 \\
\hline
\end{tabular}

* Maternal serum.

$\ddagger$ Standard error.

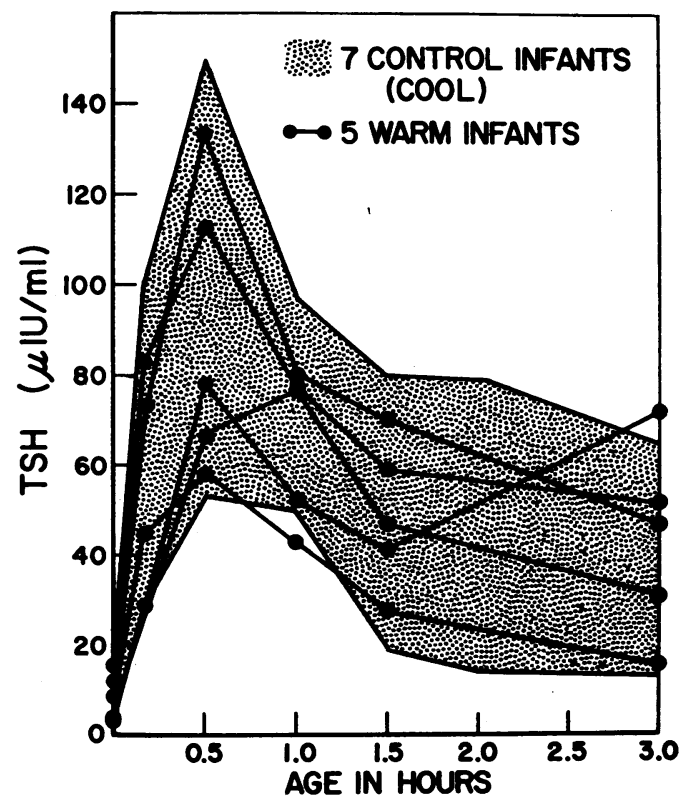

FIGURE 1 The effect of warming during the first $3 \mathrm{hr}$ on serum thyrotropin (TSH) concentration in the newborn. Serum TSH concentrations in five infants incubated at 99 $103^{\circ} \mathrm{F}$ are plotted individually. Rectal temperature in these five infants was maintained above $99^{\circ} \mathrm{F}$ throughout the $3 \mathrm{hr}$ study period. The range of values in seven infants kept at ambient nursery temperature $\left(72-78^{\circ} \mathrm{F}\right)$ is shown as background shaded area.

than in cord blood, whereas TSH concentrations are two times higher in cord blood than in maternal blood. Any cross-reaction by HCG would result in underestimation of the maternal-cord blood TSH difference.

Immunologic cross-reaction between TSH antiserum

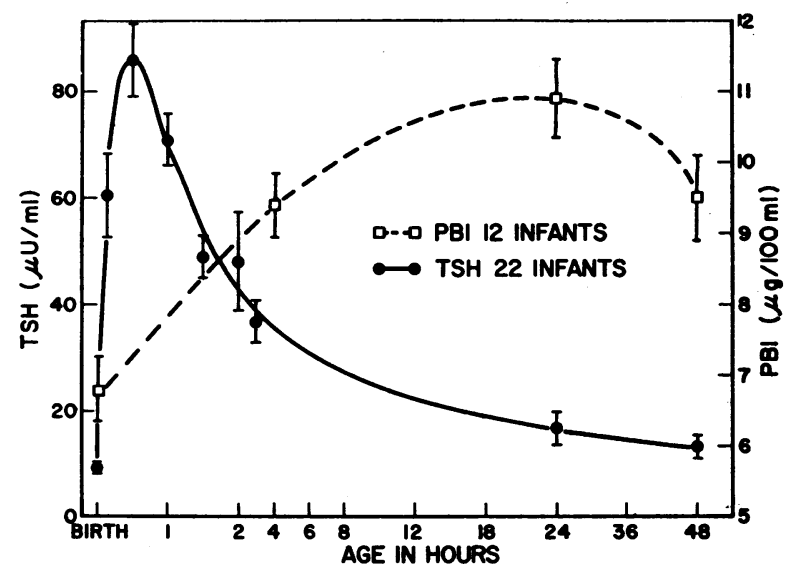

FIgURe 2 Serum protein-bound iodine (PBI) and TSH concentrations during the first $48 \mathrm{hr}$ of extrauterine life. The mean ISEM values shown in Tables I and II are plotted. Note the change in time scale on the abscissa. TSH concentrations are plotted against the left ordinate, $\mathrm{PBI}$ values against the right.

Acute Release of Thyrotropin in the Newborn

1673 


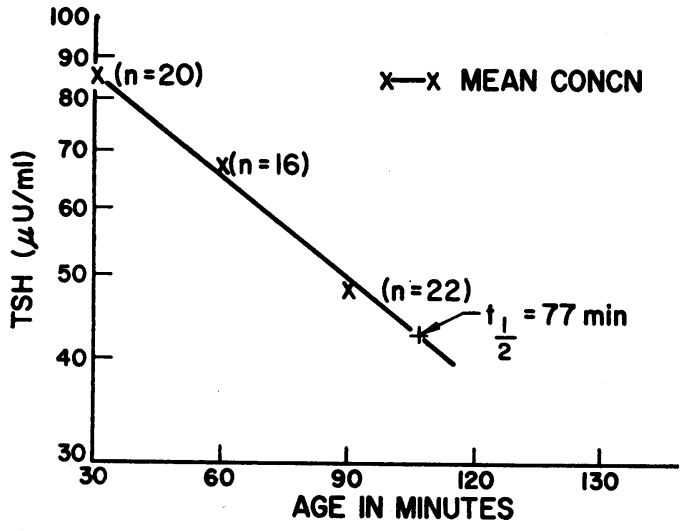

FIGURE 3 Rate of fall of serum TSH from the 30 min peak concentration. The mean 30,60 , and $90 \mathrm{~min}$ serum TSH concentrations from Table I are plotted on a logarithmic scale against age in minutes. The decrease in peak TSH concentration plotted in this way is nearly linear between 30 and $90 \mathrm{~min}$ with a half time of disappearance of $77 \mathrm{~min}$.

and human chorionic placental thyrotropin (HCT) also is unlikely as an explanation for the higher cord blood TSH concentrations. Hennen, Pierce, and Freychet (22) have reported extracting and concentrating HCT by the same techniques utilized for purification of human pituitary TSH. They achieved a 3000- to 4000 -fold purification and a final potency of about $0.5 \mathrm{U} / \mathrm{mg}$. We have conducted radioimmunoassay of HCT purified in this way using the antiserum employed in the present investigation." Although the dose-response curve for HCT paralleled that of human pituitary TSH, about 2000 times as much HCT was required, on a weight basis, to produce a radioimmunoassay reaction comparable to pituitary TSH (21).

We have shown that serum TSH concentrations in cord blood samples from caesarean section infants before their removal from the uterus, and fetal scalp blood collected during delivery (9-177 $\mathrm{min}$ before delivery of the head) also exceed maternal serum TSH concentrations. Mean cord blood and maternal TSH concentrations were $7.5 \pm 1.2$ and $3.9 \pm 0.32 \mu \mathrm{U} / \mathrm{ml}$ respectively in the caesarean section pairs and $9.1 \pm 1.0$ and $3.3 \pm 0.28$ $\mu \mathrm{U} / \mathrm{ml}$ respectively in the paired samples collected during labor (mean \pm SEM see reference 21). These data indicate that the cord blood TSH concentrations are not artifactually elevated by brief extrauterine exposure or by the "trauma" of vaginal delivery.

The observation of higher TSH levels in cord blood than in maternal blood is compatible with other data regarding newborn thyroid function. Fisher, Oddie, and Burroughs (10) have previously reported that thyroidal radioiodine clearance, measured within a few

${ }^{2} \mathrm{HCT}$ provided by courtesy of Doctors Hennen and Pierce.

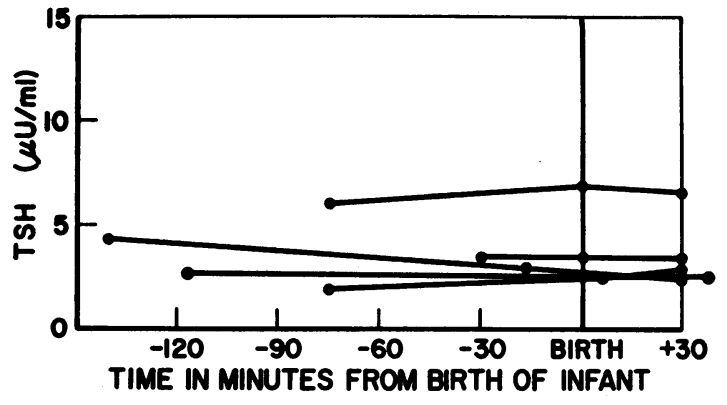

FIgure 4 Maternal serum TSH concentrations during the perinatal period. Serum TSH concentrations in five women are shown $15-140 \mathrm{~min}$ before birth, at, or near the time of birth and 30-40 min postpartum. Serum TSH concentrations were stable throughout this period.

minutes after birth, is relatively high. Total serum thyroxine concentrations are similar in maternal blood and cord blood of term infants (as in the present data, Table II), whereas the binding capacity of thyroxinebinding inter-alpha globulin is higher in maternal than cord blood (23). Thus the proportion of dialyzable thyroxine $(21,24,25)$ and the free thyroxine concentration (21) are higher in cord blood and the placental gradient for thyroxine in the term fetus is fetal-maternal. The high fetal free thyroxine concentration presumably reflects a high fetal thyroxine requirement $(26,27)$ maintained by the higher serum TSH concentration.

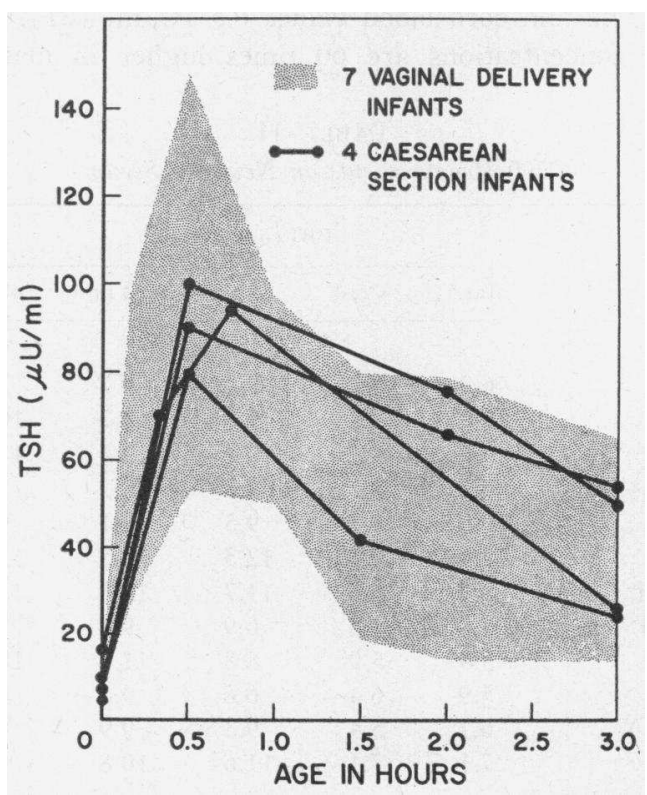

FIGURE 5 Effect of vaginal vs. caesarean section delivery on newborn serum TSH concentrations. Serum TSH concentrations are shown individually for four infants delivered by caesarean section. The shaded background represents the range of values in seven infants delivered vaginally. 
Abnormal function of the hypothalamic-pituitary control mechanism cannot be excluded.

During the early min of postnatal life, serum TSH concentrations increase rapidly to a peak level of 86 $\mu \mathrm{U} / \mathrm{ml}$ at $30 \mathrm{~min}$ (Table I, Fig. 2). This TSH must be released from the newborn pituitary gland; the low cord blood TSH levels and the lack of a $30 \mathrm{~min}$ TSH peak in the three infants with low APGAR scores would exclude a maternal or placental origin for the neonatal hyperthyrotropinemia. Moreover, the $30 \mathrm{~min}$ increment in serum TSH occurs too rapidly and is too great to be accountable by redistribution within body fluids.

The mean half-time of the decrease in serum TSH concentration between 30 and $90 \mathrm{~min}$ was $77 \mathrm{~min}$. Whether this value is a valid estimate of the degradation rate of TSH in the newborn cannot be determined from the present data since the rate of TSH secretion between 30 and $90 \mathrm{~min}$ is not known. The mean halflife measured under the present conditions would, therefore, tend to exceed the true value. The half-life of radioiodinated TSH measured in adult subjects by Odell, Wilbur, and Utiger ranged from 39 to $68 \mathrm{~min}$ (28). The present data do indicate, however, that the early rapid rate of TSH release ceases by $30 \mathrm{~min}$ and suggest that the early serum peak resulted from the rapid release of a preformed pool of pituitary TSH.

An alternative hypothesis is that TSH is chronically hypersecreted in utero to maintain serum concentrations in the face of a high rate of degradation by the pla-

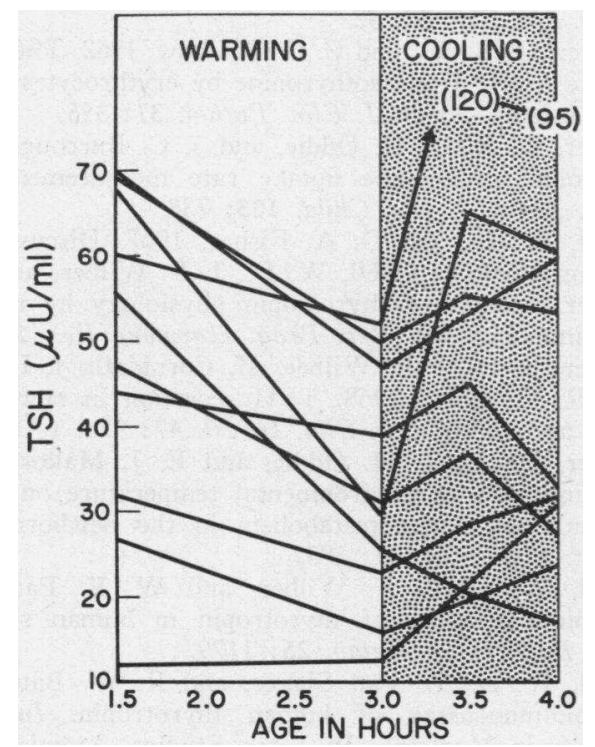

FIGURE 6 The effect of delayed cooling on serum TSH concentration in the newborn infant. Serum TSH concentrations are plotted individually for 10 infants warmed during the first $3 \mathrm{hr}$ of life $\left(99-103^{\circ} \mathrm{F}\right)$ ' and cooled at room temperature $\left(72-78^{\circ} \mathrm{F}\right)$ between 3 and $4 \mathrm{hr}$. Serum TSH increased at $3 \frac{1}{2}$ or $4 \mathrm{hr}$ in all except one infant.

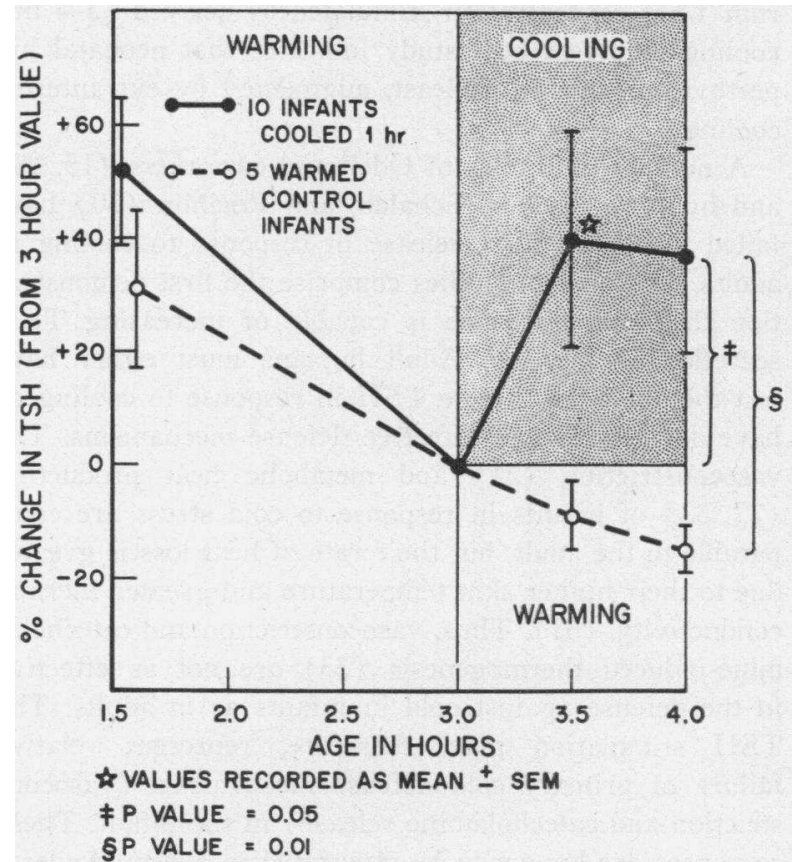

FIgURE 7 Comparison between serum TSH concentrations in warm infants and infants cooled between 3 and $4 \mathrm{hr}$ of age. Mean ( \pm SEM) per cent change in serum TSH concentrations in 10 infants warmed during the first $3 \mathrm{hr}$ (99$\left.103^{\circ} \mathrm{F}\right)$ and cooled between 3 and $4 \mathrm{hr}\left(72-78^{\circ} \mathrm{F}\right)$ are plotted against mean ( SEM $_{\text {) }}$ per cent change in TSH in five infants warmed for the entire $4 \mathrm{hr}$ period. The increase in serum TSH in the cooled infants was significantly different (by $t$ test) from zero $(P=0.05)$ at $3 \frac{1}{2}$ and $4 \mathrm{hr}$. The mean increase in serum TSH in the cool infants at $4 \mathrm{hr}$ was significant at the $1 \%$ level when compared (by $t$ test) with the mean $15 \%$ decrease in the five warm infants.

centa. At birth, sudden removal of this degradative pathway in the face of the relatively sluggish thyroid response to TSH could result in a rapid increase in TSH concentrations. This hypersecretion would cease when thyroxine levels increased sufficiently to suppress the pituitary. There is presently no evidence to support a high placental TSH degradation rate, and available data would suggest the placenta is impermeable to TSH (29).

The persistence of relatively high serum TSH levels throughout the first $24-48 \mathrm{hr}$ of life (Table I, Fig. 2) indicates that this early rapid release phase was followed by a more chronic TSH hypersecretion. The resulting hyperthyroxinemia is maximal at about $24 \mathrm{hr}$ of age.

We were unable in the present study to prevent the early, acute release of TSH by warming the infants. This result might have been due to our inability to prevent some skin cooling during the early minutes after delivery or may indicate that a more potent stimulus related to birth was operational. The increase in se- 
rum TSH concentration stimulated by delayed ( $3-4 \mathrm{hr}$ ) cooling in the present study indicates that neonatal hyperthyroxinemia is, at least, augmented by extrauterine cooling.

A number of studies of Odell and coworkers $(15,28)$ and by Berg, Utiger, Schalch, and Reichlin (30) have failed to reveal TSH release in response to cooling in adults. The present studies comprise the first demonstration that cold exposure is capable of increasing TSH secretion in humans. Adult humans must either have lost the ability to secrete TSH in response to cooling or have developed more effective defense mechanisms. The vasoconstriction (31) and metabolic heat production $(32,33)$ of infants in response to cold stress are comparable to the adult, but their rate of heat loss is greater due to their higher skin temperature and greater thermal conductivity. (31). Thus, vasoconstriction and catecholamine-induced thermogenesis (33) are not as effective in the defense against cold in infants as in adults. The TSH stimulation may, therefore, represent relative failure of primary cold defense mechanisms (vasoconstriction and catecholamine release) in the infant. These responses are known to be integrated in sheep; Andersson and colleagues (34) have shown that hypothalamic cooling of sheep stimulates both catecholamine and TSH release, and that hypothyroidism augments the catecholamine response to hypothalamic cooling. By analogy, it might be postulated that the failure of catecholaminestimulated thermogenesis to maintain body temperature may augment the thyroid response in the newborn.

Neonatal thyroidal hyperactivity and(or) hyperthyroxinemia also have been observed in newborn pigs, calves, and lambs, species in which hypothalamic-pituitary integration is well developed at birth (35-37). In the rabbit and rat, however, species in which adult integration of hypothalamic-pituitary function is delayed 14-16 days, neonatal thyroid stimulation is less marked $(37,38)$. This has been taken as evidence in favor of the hypothesis that neonatal thyroid stimulation represents a response to extrauterine cooling mediated by the hypothalamus (37). This view is supported by the observation that the rate of release of thyroidal- ${ }^{210} \mathrm{I}$ and the conversion ratio of inorganic iodine in young pigs are greater at low ambient temperatures (39). The present data would further support the hypothesis that neonatal thyroidal hyperactivity is, at least in part, a response to cooling. Our failure to suppress the acute release of thyrotropin by warming would support the view that another stimulus to TSH release is also involved.

\section{ACKNOWLEDGMENTS}

We are grateful to Mrs. Claire Pierce for technical assistance with the thyrotropin radioimmunoassays and to Mrs. Isabelle Olson and Mrs. Beverly Fisher for preparation of the manuscript. The hypothesis concerning placental TSH degradation was originally suggested by Dr. Crane Charters and Dr. Margaret Davidson. We are grateful to Dr. Bijan Siassi for his invaluable assistance with these studies.

This work was supported by U. S. Public Health Service Grant AM 12475 from the National Institute of Arthritis and Metabolic Diseases.

\section{REFERENCES}

1. Danowski, T. S., S. Y. Johnston, W. D. Price, M. Mckelvey, S. S. Stevenson, and E. R. McClusky. 1951. Protein bound iodine in infants from birth to one year of age. Pediatrics. $7: 240$.

2. Man, E. B., D. E. Pickering, J. Walker, and R. E. Cooke. 1952. Butanol-extractable iodine in the serum of infants. Pediatrics. 9: 32.

3. Pickering, D. E., N. E. Kontaxis, R. C. Benson, and R. J. Meechan. 1958. Thyroid function in the perinatal period. Amer. J. Dis. Child. 95: 616.

4. Fisher, D. A., and T. H. Oddie. 1964. Neonatal thyroidal hyperactivity. Amer. J. Dis. Child. 107: 574.

5. Perry, R. E., J. E. Hodgman, and P. Starr. 1965. Maternal, cord and serial venous blood: protein-bound iodine, thyroid binding globulin, thyroid-binding albumin and prealbumin values in premature infants. Pediatrics. $35: 759$.

6. Marks, J. F., M. Hamlin, and P. Zack. 1966. Neonatal thyroid function. II. Free thyroxine in infancy. $J$. Pediat. 68: 559.

7. Spafford, N. R., E. A. Carr, Jr., G. H. Lowrey, and W. H. Beierwaltes. 1960. In labeled triiodothyronine erythrocyte uptake of mothers and newborn infants. Amer. J. Dis. Child. 100: 844.

8. Marks, J., J. Wolfson, and R. Klein. 1961. Neonatal thyroid function: erythrocyte $T_{8}$ uptake in early infancy. J. Pediat. 58: 32.

9. Hunter, O. B., Jr., and C. C. T. Chow. 1962. The in vitro uptake of $\mathrm{I}^{131}$-1-triiodothyronine by erythrocytes of newborn infants. Amer. J. Clin. Pathol. 37: 355.

10. Fisher, D. A., T. H. Oddie, and J. C. Burroughs. 1962. Thyroidal radioiodine uptake rate measurement in infants. Amer. J. Dis. Child. 103: 738.

11. Odell, W. D., and D. A. Fisher. 1967. Discussion following article of Odell, W. D., J. F. Wilber, and R. D. Utiger. Studies of thyrotropin physiology by means of radioimmunoassay. Rec. Prog. Hormone Res. 23: 47.

12. Utiger, R. D., J. F. Wilber, M. Cornblath, J. P. Harm, and R. E. Mack. 1968. TSH secretion in newborn infants and children. J. Clin. Invest. 47: 97a. (Abstr.)

13. Fisher, D. A., T. H. Oddie, and E. J. Makoski. 1966. The influence of environmental temperature on thyroid, adrenal, and water metabolism in the newborn human infant. Pediatrics. 37: 583.

14. Odell, W. D., J. F. Wilber, and W. E. Paul. 1965. Radioimmunoassay of thyrotropin in human serum. $J$. Clin. Endocrinol. Metab. 25: 1179.

15. Odell, W. D., L. Van Slager, and R. W. Bates. 1968. Radioimmunoassay of human thyrotropin. In Radioisotopes in Medicine: In Vitro Studies. Atomic Energy Commission Symposium series. 13: 185.

16. Foss, O. P., L. V. Hankes, and D. D. Van Slyke. 1960. A study of alkaline ashing method for determination of protein-bound iodine in serum. Clin. Chim. Acta. 5: 301.

17. Apgar, V. 1953. Proposal for new method of evaluation of newborn infant. Anesth. Analg. 32: 260. 
18. Costa, A., F. Cottino, M. Dellepiane, G. M. Ferraris, L. Lenart, G. Magro, G. Patrito, and G. Zoppetti. 1965. Thyroid Function and thyrotropin activity in mother and fetus. In Current Topics in Thyroid Research. C. Cassano and M. Andreoli, editors. Academic Press Inc., New York. 738.

19. Yamazaki, E., A. Noguchi, and D. W. Slingerland. 1961. Thyrotropin in the serum of mother and fetus. J. Clin. Endocrinol. Metab. 21: 1013.

20. Odell, W. D., L. E. Reichert, and R. W. Bates. 1968. Pitfalls in the radioimmunoassay of carbohydrate containing polypeptide hormones. Excerpta Med. Int. Congr. Ser. 161: 124.

21. Fisher, D. W., C. Hobel, and W. D. Odell. Thyroid function in the term fetus. Pediatrics. In press.

22. Hennen, G., J. G. Pierce, and P. Freychet. 1969. Human chorionic thyrotropin: further characterization and study of its secretion during pregnancy. J. Clin. Endocrinol. Metab. 29: 581.

23. Perry, R. E., J. E. Hodgman, and P. Starr. 1965. Maternal, cord and serial venous blood protein bound iodine, thyroid binding globulin, thyroid binding albumin and pre-albumin values in premature infants. Pediatrics. 35: 759.

24. De Nayer, Ph., P. Malvaux, H. G. Van Den Schrieck, C. Beckers, and M. De Visscher. 1966. Free thyroxine in maternal and cord blood. J. Clin. Endocrinol. Metab. 26: 233.

25. Marks, J. F., M. Hamlin, and P. Zack. 1966. Neonatal thyroid function. II. Free thyroxine in infancy. J. Pediat. 68: 559.

26. Fisher, D. A., and T. H. Oddie. 1963. Thyroxine secretion rate during infancy: effect of estrogen. J. Clin. Endocrinol. Metab. 23: 811.

27. Cottino, F., G. Colombo, G. C. Ferrara, and A. Costa. 1961. Investigations on the metabolism of the thyroid hormone in children by means of radiothyroxine. Panminerva Med. 3: 471.

28. Odell, W. D., J. F. Wilber, and R. D. Utiger. 1967. Studies of thyrotropin physiology by means of radioimmunoassay. Recent Progr. Hormone Res. 23: 47.
29. Shepard, T. H. 1969. Development of the thyroid gland, in endocrine and genetic diseases of childhood. L. I. Gardner, editor. W. B. Saunders Company, Philadelphia. 204.

30. Berg, G. R., R. D. Utiger, D. S. Schalch, and S. Reichlin. 1966. Effect of central cooling in man on pituitarythyroid function and growth hormone secretion. J. Appl. Physiol. 21: 1791.

31. Day, R. 1943. Respiratory metabolism in infancy and childhood. XXVII. Regulation of body temperature of premature infants. Amer. J. Dis. Child. 65: 376.

32. Brück, K. 1961. Temperature regulation in the newborn infant. Biol. Neonatorum. 3: 65.

33. Schiff, D., L. Stern, and J. Leduc. 1966. Chemical termogenesis in newborn infants: catecholamine excretion and the plasma non-esterified fatty acid response to cold exposure. Pediatrics. 37: 577.

34. Andersson, B., L. Ekman, B. Hökfelt, M. Jobin, K. Olsson, and D. Robertshaw. 1967. Studies of the importance of the thyroid and the sympathetic nervous system in the defence to cold of the goat. Acta Physiol. Scand. 69: 111.

35. Lewis, R. C., and N. P. Ralston. 1953. Changes in the plasma level of protein-bound iodine in the young calf. J. Diary Sci. 36: 363.

36. Slebodzinski, A. 1965. Physiological significance of thyroxine-binding by proteins: the relationship between changes in thyroxine-binding globulin capacity and the daily utilization rate of thyroxine in the newborn pig. J. Endocrinol. 32: 65.

37. Slebodzinski, A., and Z. Srebro. 1968. The thyroid gland and the neurosecretory activity of the hypothalamus in the newborn rabbit. J. Endocrinol. 42: 193.

38. Florsheim, W. H., M. A. Faircloth, N. L. Corcorran, and P. Rudko. 1966. Perinatal thyroid function in the rat. Acta Endocrinol. 52: 375.

39. Ingram, D. L., and A. Slebodzinski. 1965. Oxygen consumption and thyroid gland activity during adaptation to high ambient temperatures in young pigs. Res. Vet. Sci. 6: 522 . 